\title{
Anti-Urolithiatic Activity of Filipendula ulmaria Leaf Extracts in Male Albino Rats
}

\author{
Rabab M. Aljarari* ${ }^{* 1}$ and Muna O. Alamoudi ${ }^{2}$ \\ ${ }^{1}$ Biology Department, Faculty of Science, Jeddah University, Jeddah - Saudi Arabia \\ ${ }^{2}$ Biology Departments, Faculty of Science, Hail University, Hail City - Saudi Arabia
}

\begin{abstract}
Filipendula ulmaria L. is a perennial herb that can be found in regions with higher humidity in Asia, and Europe. The herb is used medicinally as drugs for several purposes such as facilitating renal elimination functions and many other biological activities. Therefore, the present study was focus on the anti-Urolithiatic activity of Filipendula ulmaria leaf extracts using Albino rats as a model. The influence of oral administration of aqueous, methanolic and ethanolic extracts of Filipendula ulmaria leaves on accumulated calcium oxalate urolithiasis has been investigated. Nephrolithiasis was induced in the rats by oral administration of ethylene glycol $(0.75 \%)$ in drinking water for 28 days. Animals were divided into nine groups, each containing six rats. Group 1 received purified water as negative control; group 2 received ethylene glycol in drinking water; group 3 received cystone as curative agent, groups 4-9 received Filipendula ulmaria extracts in dosages of 100 and $200 \mathrm{mg} / \mathrm{kg}$ body weight, respectively. The aqueous and methanolic Leaf-extracts showed significant reduction in the urine parameters compared to ethanolic extracts. However, using the cystone showed highest reduction rate compared to the leaf-extracts using different solvents. Cystone also recorded higher impact on the serum parameters compared to the extract used. The results revealed that the Filipendula ulmaria leaf extracts have anti-urolithiatic activity against ethylene glycol-induced calcium oxalate urolithiasis in male albino rats.
\end{abstract}

Keywords: Filipendula ulmaria, Excretion, Antiurolithiatic, Ethylene glycol, Cystone.

\section{INTRODUCTION}

Filipendula ulmaria L. is known as meadowsweet, it is a perennial herbal plant with short-pink rhizome and creamy-white flowers. The stem is erect, furrowed and reaches 50 up to $120 \mathrm{~cm}$ tall. The leaves are pinnate with serrate margin and dark green in color at the upper side (Tucakov and Beograd, 1973). F. ulmaria can be found in higher humidity areas in Asia, and Europe, meadows, and swamps (Tucakov and Beograd, 1973). Several biological activities of Filipendula ulmaria have been explored and proved the ability of using this plant as antibacterial, antioxidant, anti-proliferative and anti-inflammatory mediator (Katanic et al., 2017).

The whole herb including the rhizomes, leaves and flowers are used medicinally as drugs (Tucakov and Beograd, 1973). They are used in the form of aqueous-extracts, ointments, tinctures, and decoctions (Gorbacheva et al., 2005). The herb and its flowers are also listed for treatment of urinary problems, gout, fever, infections, and joint pain. The flower, as component of mixed herbal tea, is used as remedies for rheumatism, influenza, and Kidney-bladder ailments (Jaric et al., 2007; Voglet et al., 2013). Meanwhile, the aqueous extract of Filipendula ulmaria leave is used for the treatment of wound, burns, tropic ulcer, and the lower extremities (Vysochina et al., 2013). Additionally, the top of the dried flowers is traditionally used to facilitate digestive and renal elimination functions (Ema, 2011).

Urolithiasis is among kidney disease in which the sedimentation of less soluble and insoluble salts, in the form of oxalate and phosphate, developed in the urinary tract (Sharma and Lamichhane, 2017). The accumulation of oxalate and phosphate mainly occurs in the form of $(50 \%)$ calcium oxalate and $(5 \%)$ calcium phosphate salts, which covering $75 \%$ of all calculi (Shirfuleet et al., 2013). This process results in obstruction of the urethra which leads to pyuria, hematuria, renal colic, dysuria, and oliguria (Sharma and Lamichhane, 2017). The incidence of kidney stones in males and females has been increased in the past years. The recurrence rate of this condition is higher in males compared to females; $70-80 \%$ in males, and $47-60 \%$ in females (Mikawlrawng and Kumar, 2014). Nevertheless, stone disease has been more common among men than women due to the presence of high level testosterone hormone that stimulate the formation of stone (Sharma, and Lamichhane.2017), but the differential changes in dietary behaviour intake, amount of fluid intake, and obesity in men and women may be the reason shifts in stone disease incidence and prevalence. Meanwhile, there is no previous studies reported the role of Filipendula ulmaria leaf-extract on the renal function or its anti-urolithiatic activity. Therefore, this study was carried out to conduct and investigate such activity of the leaf-extract of $F$. ulmaria using Albino rats as a model.

\section{MATERIALS AND METHODS}

\section{Plant material}

F. ulmaria L. is perennial member of Family Rosaceae, and belongs to order Rosales. Its compound leaves were collected from the Faculty of Agriculture, Mansoura University, Mansoura, Egypt (Figure 1). The air-dried leaves were crushed to a powder and then subjected to extraction. Water and other solvents were used for extraction.

Aqueous extract was prepared following the method of Fernando et al., (1989), in which $200 \mathrm{~g}$ of the plant powder was macerated in $500 \mathrm{ml}$ of distilled water in 
1L flask and boiled for $1 \mathrm{hr}$. The extract was cooled to $40^{\circ} \mathrm{C}$ and then filtered using Whattman No.1 filter paper. In a rotary evaporator under vacuum $\left(40^{\circ} \mathrm{C}\right)$, the filtrate was concentrated and stored at $4{ }^{\circ} \mathrm{C}$ for further usage.

For alcoholic extracts, methanol and ethanol, in sequential, were used in which $200 \mathrm{~g}$ of plant powder was socked in methanol ( $3 \mathrm{~L})$ for six times at room temperature, then the successive extraction was carried out by using ethanol. Both methanolic and ethanolic extracts were subjected to concentrate using rotary evaporator at $40^{\circ} \mathrm{C}$. The crude extracts were kept at $4^{\circ} \mathrm{C}$ till further use. Preliminary phytochemical analyses of leaves were performed using standard methods (Washington, 2011).

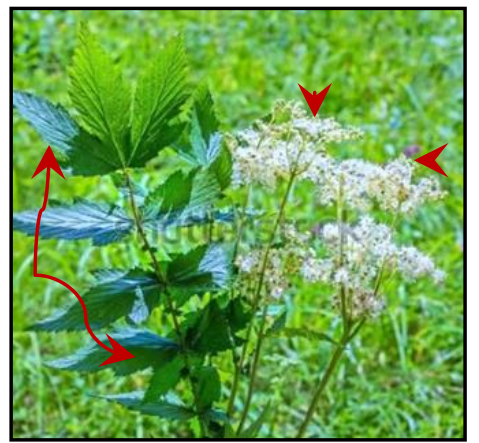

Figure 1: Filipendula ulmaria plant showing erect stem bearing compound alternate leaves (arrows) and bunches of attractive, fragrant white flowers (head arrows).

\section{Experimental animals}

Male albino rats of 175- $200 \mathrm{~g}$ weight were used. The animals were nourished with standardized animal chow and water ad libitum. The rats were adapted under controlled conditions of humidity of $50 \pm 5 \%$, temperature of $28 \pm 2{ }^{\circ} \mathrm{C}$, and $10-12 \mathrm{~h}$ of light and dark cycles for one week. Animal experiments were performed according to the guide for the humane care and use of laboratory animals.

\section{Acute toxicity studies}

The animals were fasted from food overnight. Acute oral toxicity assessment was done using both the aqueous, methanolic and ethanolic extracts (based on OECD guidelines, 1995) at dose range 250 to 2500 $\mathrm{mg} / \mathrm{kg}$. The toxic dose was defined if mortality was observed in two out of three animals. If the death was seen in one animal, than the same dose was repeated again, and if death was not seen, the procedure was performed for the higher dose, up to $2500 \mathrm{mg} / \mathrm{kg}$. The animals were observed for $24 \mathrm{hr}$ for body temperature, neurological, autonomic and behavioral profiles (Sofowora, 1993).

\section{Experimental design}

The animals were differentiated into nine groups; each group containing six rats. Group 1, was the normal negative control which received regular feed and drinking water ad libitum. The other eight groups were administered $0.75 \%(\mathrm{v} / \mathrm{v})$ of ethylene glycol to induce kidney-calculi (Urolithiasis). Ethylene glycol (EG) was applied in drinking water for 28 days. Group 2, was the model positive control which received no treatment after administered EG for 28 days. Group 3; was the standard group which received Cystone $750 \mathrm{mg} / \mathrm{kg}$ body weight (Sigma Company, Egypt) as reference standard for curing (Wang et al., 2020). Groups 4, 5, 6, 7, 8 and 9; were the groups under treatment which received plant extracts at doses of 100 and $200 \mathrm{mg} / \mathrm{kg}$ body weight, respectively, along the study period. For minute details, groups 4 and 5 were calculi-induced rats and orally administered aqueous $F$. ulmaria extracts at 100 and $200 \mathrm{mg} / \mathrm{kg} \mathrm{BW}$, respectively. Meanwhile, groups 6 and 7 were calculi-induced and treated with methanolic extract at 100 and $200 \mathrm{mg} / \mathrm{kg}$ BW, respectively. Groups 8 and 9 were calculi-induced and treated with ethanolic extract at 100 and $200 \mathrm{mg} / \mathrm{kg}$ BW, respectively. Standard drug and $F$. ulmaria extracts were administered daily using the gastric tube.

\section{Urine analysis}

The $24 \mathrm{hr}$ urine samples were collected from the rats on the $28^{\text {th }}$ day. A drop of concentrated hydrochloric acid was mixed with the urine before the storage of urine which was done at $4{ }^{\circ} \mathrm{C}$. After then urine analysis was carried out for volume, and $\mathrm{pH}$. Calcium, oxalate, uric acid and citrate content by colorimetric procedure (Hodgkinson and Williams, 1972). For phosphorus content, molybdenum blue reaction was done (Gindler and Heth, 1971). The urine samples were centrifuged for $10 \mathrm{~min}$ at $3000 \mathrm{rpm}$, and then the urine samples were examined under light microscope to investigate the calcium oxalate crystals.

\section{Analysis of the Serum}

The blood was collected from the retro-orbital puncture of animal before scarification. Serum was obtained by centrifugation for $10 \mathrm{~min}$ at $10,000 \mathrm{~g}$. Estimation of urea, creatinine, and blood urea nitrogen content was done using commercially available kits and a colorimetric method was used for the determination of uric acid (Fossatiet et al., 1980).

\section{Kidney homogenate analysis}

The two kidneys were obtained from the animals by incision of the abdomen. The kidneys were then cleaned off extraneous tissue, and weighed then rinsed with ice cold normal saline. The right kidney was finally chopped and $20 \%$ homogenate was prepared in Tris- $\mathrm{HCl}$ buffer ( $\mathrm{pH}$ 7.4). Total kidney homogenate was used for assaying tissue calcium and oxalate, (Hodgkinson, 1970). Commercially available kits (Span Diagnostics Ltd., India) were used for the estimation the levels of superoxide dismutase (SOD) and reduced glutathione (GSH). Additionally, malondialdehyde (MDA), which is a product of lipid peroxidation was also determined.

\section{Statistical analysis}

Data obtained were analysis for significant differrences between designed groups. Arithmetic mean \pm SD were calculated and used for representing quantitative data. ANOVA was performed followed by Dunnett's test to evaluate the level of significance using sigma plot software (System software Inc., USA, Version: 10.0.1). $P$-value at 0.05 levels was considered statically significant. 


\section{RESULTS}

The preliminary phytochemical tests of $F$. ulmaria revealed the presence of polyphenols, flavonoids, saponins, alkaloids, carbohydrates, glycosides, steroids and triterpenoids in the aqueous, methanolic and ethanolic extracted leaves.

\section{Effect of $F$. ulmaria leaves extracts on the urine parameters}

The impact of the three extracts of $F$. ulmaria leaves on the urine parameters are shown in table (1). Regarding group two (ethylene glycol group), there was increase in the mean of urine volume, $\mathrm{pH}$, calcium, oxalate, uric acid, and phosphate compared to the normal control, whereas there was a reduction in the mean of citrate compared to the normal control group. Regarding cystone group, there was increase in the mean of all urine parameters compared to the normal control group. There was elevation in the mean of urine volume, and citrate of cystone group compared to the ethylene glycol group, whereas there was reduction in the mean of other parameters in cystone group compared to the ethylene glycol group.
The two groups of the aqueous extract showed significant reduction in the group of $200 \mathrm{mg} / \mathrm{Kg}$ compared to the group used the concentration of $100 \mathrm{mg} / \mathrm{Kg}$ regarding $\mathrm{pH}$, calcium, oxalate, uric acid, and phosphate, whereas there was increase in the mean of urine volume and citrate in the group used the higher concentration of the extract. In comparison to the ethylene glycol group, the two groups of aqueous extract showed reduction in the mean of all parameters except for citrate which showed an increase in the two groups of the aqueous extracts. Compared to cystone group, the reduction was regarding the urine volume and citrate.

In the methanolic extract groups, there was significant reduction in all parameters compared to the aqueous extract groups, except for urine volume and citrate which showed increase in the methanolic groups. By comparing the methanolic groups with the cystone group, there was an increase in the mean of calcium, oxalate, phosphate and citrate based on the concentration of the methanolic extract used.

Regarding the ethanolic groups, there was reduction in the volume of urine and citrate compared to cystone

Table (1): Effects of Filipendula ulmaria leaf-extracts on urine parameters in urolithiasis-induced rats

\begin{tabular}{lcccccccc}
\hline \hline $\begin{array}{l}\text { Treatment } \\
\text { (Group) }\end{array}$ & $\begin{array}{c}\text { Dose } \\
(\mathbf{m g} / \mathbf{k g ~ B W})\end{array}$ & U-volume & $\mathbf{p H}$ & $\begin{array}{c}\text { Calcium } \\
\text { content } \\
(\mathbf{m g} / \mathbf{g})\end{array}$ & $\begin{array}{c}\text { Oxalate } \\
\text { content } \\
(\mathbf{m g} / \mathbf{g})\end{array}$ & $\begin{array}{c}\text { Uric acid } \\
(\mathbf{m g} / \mathbf{d L})\end{array}$ & $\begin{array}{c}\text { Phosphate } \\
(\mathbf{m g} / \mathbf{d L})\end{array}$ & $\begin{array}{c}\text { Citrate } \\
(\mathbf{m g} / \mathbf{d L})\end{array}$ \\
\hline G 1 & -- & $10.65 \pm 0.09$ & $6.33 \pm 0.12$ & $4.70 \pm 0.33$ & $3.30 \pm 0.04$ & $1.40 \pm 0.00$ & $4.70 \pm 0.01$ & $46.88 \pm 2.22$ \\
G 2 & -- & $15.00 \pm 0.12$ & $8.01 \pm 0.00$ & $8.08 \pm 0.03$ & $7.88 \pm 0.36$ & $3.22 \pm 0.24$ & $7.55 \pm 0.00$ & $32.46 \pm 1.52$ \\
G 3 & 750 & $22.12 \pm 0.18$ & $6.80 \pm 0.54$ & $4.72 \pm 0.00$ & $3.80 \pm 0.20$ & $1.70 \pm 0.08$ & $5.30 \pm 0.26$ & $47.02 \pm 0.01$ \\
G 4 & 100 & $18.97 \pm 1.16$ & $7.19 \pm 0.07$ & $5.47 \pm 0.13$ & $5.66 \pm 0.54$ & $2.31 \pm 0.41$ & $6.49 \pm 0.35$ & $38.00 \pm 0.71$ \\
G 5 & 200 & $19.07 \pm 0.09$ & $7.04 \pm 0.11$ & $5.29 \pm 0.07$ & $5.00 \pm 0.21$ & $2.14 \pm 0.01$ & $6.01 \pm 0.01$ & $41.00 \pm 0.01$ \\
G 6 & 100 & $21.00 \pm 0.12$ & $6.70 \pm 0.53$ & $4.98 \pm 0.61$ & $4.84 \pm 0.34$ & $1.90 \pm 0.29$ & $5.73 \pm 0.56$ & $45.24 \pm 3.06$ \\
G 7 & 200 & $21.91 \pm 1.05$ & $6.51 \pm 0.31$ & $4.55 \pm 0.00$ & $4.07 \pm 0.01$ & $1.49 \pm 0.61$ & $5.22 \pm 0.00$ & $47.00 \pm 0.00$ \\
G 8 & 100 & $20.24 \pm 1.55$ & $6.88 \pm 0.81$ & $5.25 \pm 0.56$ & $5.78 \pm 0.63$ & $2.06 \pm 0.46$ & $6.14 \pm 0.63$ & $43.53 \pm 4.62$ \\
G 9 & 200 & $21.00 \pm 0.01$ & $6.68 \pm 0.05$ & $4.90 \pm 0.47$ & $4.58 \pm 0.00$ & $1.91 \pm 0.03$ & $5.81 \pm 0.53$ & $45.00 \pm 0.18$ \\
\hline \hline
\end{tabular}

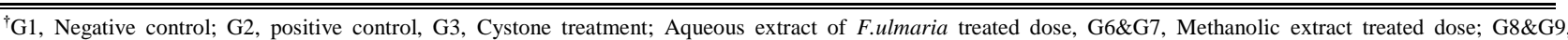
Ethanolic extract treated dose.

group, whereas other parameters showed increase in the mean value compared to the cystone group.

\section{Effect of $F$. ulmaria leaf- extracts on the serum parameters}

The effect of $F$. ulmaria leaf-extracts on the serum parameters in rats is shown in table (2). In ethylene glycol group, there was increase in the mean of creatinine, uric acid, urea and blood UN compared to the normal control. Cystone showed significant reduction in all parameters of the serum compared to the ethylene glycol group. The two groups of aqueous extracts showed significant reduction the serum parameters compared to the ethylene glycol group, whereas the reduction in cystone group was higher compared to the two aqueous groups. There reduction in the serum parameters in the two methanolic groups; this reduction was more than the reduction in the aqueous groups, and less than the reduction of cystone group. Also, the ethanolic extract was more effective on the serum parameters compared to the aqueous extract, but less effective compared to the cystone as a standerd curative agent.

\section{Effect of Filipendula ulmaria leaves extract on the kidney parameters}

The impact of the leave extract of the plant on the kidney parameters is shown in table (3). In ethylene glycol group, there was increase in the kidney parameters, except for GSH, and SOD which were reduced.The cystone group showed reduction in kidney parameters compared to the ethylene glycol group, except for GSH, and SOD which showed an increase compared to the ethylene glycol group. Regarding the 
Table (2): Effects of Filipendula ulmaria leaf-extracts on serum parameters in urolithiasis-induced rats.

\begin{tabular}{cccccc}
\hline \hline $\begin{array}{c}\text { Treatment }^{\dagger} \\
(\mathbf{G r o u p})\end{array}$ & $\begin{array}{c}\text { Dose } \\
(\mathbf{m g} / \mathbf{k g})\end{array}$ & $\begin{array}{c}\text { Creatinine level } \\
(\mathbf{m g} / \mathbf{d L})\end{array}$ & Uric acid & Urea & Blood U.N \\
\hline G 1 & -- & $0.74 \pm 0.04$ & $3.12 \pm 0.22$ & $15.98 \pm 0.44$ & $36.00 \pm 2.28$ \\
G 2 & -- & $2.14 \pm 0.48$ & $5.66 \pm 0.02$ & $28.00 \pm 1.27$ & $63.41 \pm 4.68$ \\
G 3 & 750 & $0.78 \pm 0.18$ & $3.41 \pm 0.21$ & $17.88 \pm 2.55$ & $40.00 \pm 2.23$ \\
G 4 & 100 & $1.42 \pm 0.05$ & $4.39 \pm 0.00$ & $22.00 \pm 0.25$ & $50.88 \pm 2.04$ \\
G 5 & 200 & $1.30 \pm 0.16$ & $4.04 \pm 0.11$ & $20.07 \pm 0.20$ & $48.92 \pm 0.00$ \\
G 6 & 100 & $0.90 \pm 0.04$ & $3.90 \pm 0.03$ & $19.42 \pm 1.08$ & $44.00 \pm 1.07$ \\
G 7 & 200 & $0.82 \pm 0.00$ & $3.40 \pm 0.00$ & $18.00 \pm 0.09$ & $42.00 \pm 0.09$ \\
G 8 & 100 & $0.98 \pm 0.33$ & $4.00 \pm 0.79$ & $20.55 \pm 0.34$ & $47.07 \pm 1.09$ \\
G 9 & 200 & $0.89 \pm 0.15$ & $3.71 \pm 0.08$ & $19.00 \pm 1.08$ & $43.86 \pm 2.22$ \\
\hline \hline
\end{tabular}

${ }^{\dagger}$ G1, Negative control; G2, positive control, G3, Cystone treatment; G4\&G5 Aqueous extract of F.ulmaria treated dose, G6\&G7, Methanolic extract treated dose; G8\&G9, Ethanolic extract treated dose.

aqueous extract groups, also there was reduction in kidney parameters, except for GSH, and SOD which showed an increase in the mean level compared to the ethylene glycol group. The reduction and increase in the parameters in the aqueous group were lower than that of the cystone group. The same was found regarding the methanolic and ethanolic extracts with more efficacies of methanolic extracts, which was comp-arable to cystone.

\section{DISCUSSION}

Medicinal parts of Filipendula ulmaria contain a number of flavenoids, phenolic compounds, glycosides, salicylate aglycons, hydrolysable and condensed tannins (Barros et al., 2013; Papp et al., 2004; Fecka, 2009; Gniewosz et al., 2014). In this study, by the preliminary tests we found a presence of flavenoids, polyphenols, alkaloids, saponins, glycosides, carbohydrates, triterpenoids, and steroids.

The increase in the calcium in urine indicates to the precipitation of calcium, phosphate and oxalate resulting in crystal formation. The hyperabsorption of calcium results from the defective reabsorption of renal tubule (Fossati et al., 1980). The formation of stones in animals fed with ethylene glycol is resulted from hyperoxaluria, which causes elevation in the excretion of oxalate and renal retention (Afonne et al., 2020).

In the current study, the leave extracts of Filipendula ulmaria resulted in reduction in calcium, oxalate, and phosphate compared to the same parameters in the ethylene glycol group. The results showed antiUrolithiatic activity, where aqueous and methanolic extract had higher activity compared to the ethanolic extract. However, the leave extracts were less effective compared to cystone. A similar study to our, but used the extraction of Melia azedarach Linn leaves showed that the aqueous and ethanolic extract of the leaves resulted in significant reduction in the elevated level of oxalate, calcium and phosphate (Dharmalingam et al., 2014).

Regarding the serum parameters that investigated the kidney functions, the extracts of the Filipendula ulmaria leave had significant impact on the kidney functions, with ethanolic and methanolic extracts being

Table (3): Effects of Filipendula ulmaria leaf-extracts on kidney parameters in urolithiasis-induced rats.

\begin{tabular}{lccccccc}
\hline \hline $\begin{array}{l}\text { Treatment } \\
\text { (Group) }\end{array}$ & $\begin{array}{c}\text { Dose } \\
(\mathbf{m g} / \mathbf{k g})\end{array}$ & $\begin{array}{c}\text { Kidney } \\
\text { weight }(\mathbf{g})\end{array}$ & $\begin{array}{c}\text { Calcium } \\
\text { content } \\
(\mathbf{m g} / \mathbf{g})\end{array}$ & $\begin{array}{c}\text { Oxalate } \\
\text { content } \\
(\mathbf{m g} / \mathbf{g})\end{array}$ & $\begin{array}{c}\text { GSH } \\
(\boldsymbol{\mu M})\end{array}$ & $\begin{array}{c}\text { MDA } \\
(\mathbf{n m o l} / \mathbf{m g})\end{array}$ & $\begin{array}{c}\text { SOD } \\
(\mathbf{U} / \mathbf{m i n} / \mathbf{m})\end{array}$ \\
\hline G 1 & -- & $1.36 \pm 0.22$ & $3.12 \pm 0.66$ & $1.05 \pm 0.07$ & $9.12 \pm 1.77$ & $0.61 \pm 0.10$ & $6.00 \pm 0.44$ \\
G 2 & -- & $2.20 \pm 0.41$ & $5.80 \pm 0.09$ & $3.89 \pm 0.58$ & $5.10 \pm 0.12$ & $4.55 \pm 0.00$ & $2.66 \pm 0.00$ \\
G 3 & 750 & $1.41 \pm 0.02$ & $3.54 \pm 0.33$ & $1.98 \pm 0.33$ & $7.55 \pm 0.00$ & $1.51 \pm 0.16$ & $5.30 \pm 0.12$ \\
G 4 & 100 & $1.96 \pm 0.00$ & $4.33 \pm 0.00$ & $2.44 \pm 0.00$ & $6.41 \pm 0.01$ & $3.00 \pm 0.12$ & $3.80 \pm 0.19$ \\
G 5 & 200 & $1.91 \pm 0.04$ & $4.10 \pm 0.05$ & $2.20 \pm 0.11$ & $6.94 \pm 0.08$ & $2.74 \pm 0.05$ & $4.03 \pm 0.00$ \\
G 6 & 100 & $1.52 \pm 0.15$ & $3.78 \pm 0.81$ & $2.10 \pm 0.71$ & $7.12 \pm 0.47$ & $2.00 \pm 0.44$ & $5.02 \pm 0.66$ \\
G 7 & 200 & $1.42 \pm 0.00$ & $3.50 \pm 0.00$ & $1.84 \pm 0.03$ & $7.94 \pm 0.33$ & $1.44 \pm 0.09$ & $5.53 \pm 0.00$ \\
G 8 & 100 & $1.72 \pm 0.03$ & $4.01 \pm 0.07$ & $2.38 \pm 0.16$ & $6.98 \pm 0.13$ & $2.71 \pm 0.07$ & $4.50 \pm 0.00$ \\
G 9 & 200 & $1.60 \pm 0.13$ & $3.90 \pm 0.04$ & $2.08 \pm 0.00$ & $7.28 \pm 0.00$ & $2.02 \pm 0.00$ & $4.97 \pm 0.00$ \\
\hline \hline
\end{tabular}

${ }^{\dagger} \mathrm{G} 1$, Negative control; G2, positive control, G3, Cystone treatment; G4\&G5 Aqueous extract of F.ulmaria treated dose, G6\&G7, Methanolic extract treated dose; G8\&G9, Ethanolic extract treated dose. 
the most potent extracts. The methanolic and ethanolic extracts resulted in restoration of the creatinine to level near to that in the normal control group; reflecting restoration of kidney function compared to the ethylene glycol group which showed deterioration in the kidney functions. The same findings were found regarding uric acid, urea and blood UN. However, we found that Cystone was more potent compared to the leave extracts. A study used Meliaazedarach Linn leaves extract showed that ethanolic extract resulted in the restoration of serum creatinine excretion, where a deterioration of renal function was observed by elevation of serum creatinine, blood UN, and uric acid in the ethylene glycol group. This damage was treated by the ethanolic and aqueous extract of Meliaazedarach Linn leaves (Dharmalingam et al., 2014).

Another study done by Chinnala et al., (2013), investigated the anti-urolithiatic activity of Solanum virginianum extracts is also in agreement with our study. In their study, they found that the treatment using the ethanolic extract of the plant resulted in a reduction in the elevated blood UN, serum creatinine, serum uric acid, elevated calcium and phosphates.

A study conducted on Bryophyllum pinnatum leaves showed that the aqueous extract of the leaves of the plant resulted in reduction in the level of oxalate and an improvement in the level of creatinine and blood UN (Shuklaet et al., 2014). Another study on Ipomoea eriocarpa proved that the ethanolic-leaf extract resulted in restoration of the different parameters measured, level of oxalate, creatinine and blood UN, in serum, urine, and kidney homogenate. It also inhibited the growth of stones reflecting the presence of antiurolithiatic activity of the plant leave (Das and Malipeddi, 2016).

This study revealed that both methanolic and ethanolic extracts were more effective compared to aqueous extract regarding the kidney parameters. calcium and oxalate significantly were reduced in the methanolic and ethanolic groups compared to the aqueous extract group. Moreover, GSH, and SOD levels were increased in the groups of methanolic and ethanolic extracts compared to the aqueous extract groups. There was no previous study reported the variation in the levels of GSH, and SOD when studying the anti-Urolithiatic activity of any plant before.

In one study, it was reported that aqueous extract of Bryophyllum pinnatum leaves resulted in a relative reduction in the kidney weight and the deposition of calcium oxalate ((Shukla et al., 2014). This was in agreement with our findings, but this impact was observed in the groups used the methanolic and ethanolic extracts, not the aqueous extract. Additionally, a study conducted to evaluate the impact of ethanolic extract of Nigella sativa L seeds on the kidney calculi reduction, which induced by ethylene glycol, also proved with greatest extent its ability to improve the kidney function (Ardakani et al., 2019; Khoeiet et al., 2009). Their study demonstrated that the ethanolic extract of the seeds resulted in a reduction in the deposited calcium oxalate.

\section{CONCLUSION}

The extracts of Filipendula ulmaria leave have antiUrolithiatic activity. The aqueous and methanolic extracts showed significant reduction in the urine parameters compared to ethanolic extracts, referring that aqueous and methanolic extracts have antiUrolithiatic activity. Whereas the methanolic and ethanolic extracts had higher activity on the kidney function compared to the aqueous extract. Also the methanolic and ethanolic extracts had higher activity compared to the aqueous extract regarding the kidney parameters. So, ethanolic extract is more potent than aqueous extract, whereas methanolic extract is the most potent extract.

\section{REFERENCES}

AFONNE O.J., O.E. ORISAKWE, C.E. DIOKA, E. OBI, T. EZEJIOFOR, L. ASOMUGHA, AND U. UKOHA. 2002. Effects of rinbacin extract on rat kidney. Biological and Pharmaceutical Bulletin; 25(8):1022-5.

ARDAKANI MOVAGHATI MR, YOUSEFI M, SAGHEBI SA, SADEGHIVAZIN M, IRAJI A, MOSAVAT SH. 2019. Efficacy of black seed (Nigella sativa L.) on kidney stone dissolution: A randomized, double-blind, placebo-controlled, clinical trial. Phytotherapy Research., 33(5):140412.

BARROS L., C.T. ALVES, M. DUEÑAS, S. SILVA, R. OLIVEIRA, A.M. CARVALHO, M. HENRIQUES, C.SANTOS-BUELGA, AND I.C.F.R. FERREIRA. 2013. Towards antifungal compounds exploring phenolic extracts of wild medicinal flowers from Portugal. Ind. Crops and Prod;44:104-110.

CHINNALA K.M., S. SHANIGARM, AND M.M. ELSANI. 2013. Antiurolithiatic activity of the plant extracts of Solanum virginianum on ethylene glycol induced urolithiasis in rats. International Journal of Pharmacy and Biological Sciences;3:328.

DAS M., AND H. MALIPEDDI. 2016. Antiurolithiatic activity of ethanol leaf extract of Ipomoea eriocarpa against ethylene glycol-induced urolithiasis in male Wistar rats. Indian journal of pharmacology; 48(3):270.

DHARMALINGAM S.R, R. MADHAPPAN, K. CHIDAMBARAM, S. RAMAMURTHY, K. GOPAL, P. SWETHA, AND K.S. KUMAR. 2014. Anti-urolithiatic activity of Melia azedarach Linn leaf extract in ethylene glycol-induced urolithiasis in male albino rats. Tropical Journal of Pharmaceutical Research; 13(3):391-397.

EUROPEAN MEDICINES AGENCY (EMA). 2011. Assessment report on Filipendula ulmaria (L.) Maxim., herba and Filipendula ulmaria (L.) Maxim., flos. Available at: http://www.ema. europa.eu/ema, Accessed 11 October 2020.

FECKA I. 2009. Qualitative and quantitative determination of hydrolysable tannins and other polyphenols in herbal products from meadowsweet 
and dog rose. Phytochemical Analysis; 20(3):177190.

FERNANDO M.R., S.M.D.N. WICKRAMASINGHE, M.I. THABREW, E.H. KARUNANAYAKA. 1989. A preliminary investigation of the possible hypoglycaemic activity of Asteracanthus longifolia. J Ethnopharmacol; 27:7-14.

FOSSATI P., L. PRENCIPE, AND G. BERTI. 1980. Use of 3, 5-dichloro-2- hydroxy benzene sulfonic acid / 4-aminophenazone chromogenic system in direct enzymic assay of uric acid in serum and urine. Clinical Chem; 26: 227-231

GINDLER E.M., AND D.A HETH. 1971. Colorimetric determination with bound "calmagite" of magnesium in human serum. Clin Chem; 17:662664 .

Gniewosz M., A. Synowiec, K. Kraśniewska, J.L. Przybył, K. Bączek, And Z. Węglarz. 2014. The antimicrobial activity of pullulan film incorporated with meadowsweet flower extracts (Filipendula eulmariae flos) on postharvest quality of apples. Food Control;37:351-361.

GORBACHEVA A.V., S.G. AKSENENKO, AND V.G. PASHYNSKY. 2005. Labaznik vyazolistnyiy v fitoterapii vospalitelnyih protsessov. Meadowsweet in herbal medicine inflammatory processes. Tomsk, TGPU Publ, 305.

HODGKINSON A. 1970. Determination of oxalic acid in biological material. ClinChem;16:547-57.

HODGKINSON A., AND A. WILLIAMS. 1972. An Improved colorimetric procedure for urine oxalate urine. Clin. Clim. Acta; 36:127-132.

JARIC S., Z. POPOVIĆ, M. MAČUKANOVIĆJOCIĆ, L. DJURDJEVIĆ, M. MIJATOVIĆ, B. KARADŽIĆ, M. MITROVIĆ, AND P. PAVLOVIĆ. 2007. An ethnobotanical study on the usage of wild medicinal herbs from Kopaonik Mountain (Central Serbia). J. of ethnopharmacology; 111(1):160-175.

KATANIC J., S. MATIĆ, E.M. PFERSCHYWENZIG, N. KRETSCHMER, T. BOROJA, V. MIHAILOVIĆ, V. STANKOVIĆ, N. STANKOVIĆ, M. MLADENOVIĆ, S. STANIĆ, AND M. MIHAILOVIĆ. 2017. Filipendula ulmaria extracts attenuate cisplatin-induced liver and kidney oxidative stress in rats: In vivo investigation and LC-MS analysis. Food and Chemical Toxicology; 99:86-102.

KHOEI A., . ZHADJZADEH, AND M. PARIZADY. 2009. Ethanolic extract of nigella sativa $L$ seeds on ethylene glycol-induced kidney calculi in rats. Urology journal; 4(2):.86-90.

MIKAWLRAWNG K., AND S. KUMAR. 2014. Current scenario of urolithiasis and the use of medicinal plants as anti-urolithiatic agents in Manipur (North East India): a review. International Journal of Herbal Medicine; 2(1):1-2.

OECD. 1995. Guidelines for the testing of chemicals. (No.407, Section 4: Health Effects) Repeated Dose 28-Day Oral Toxicity in Rodents, 27.

PAPP I., P. APATI, V. ANDRASEK, A. BLÁZOVICS, A. BALÁZS, L. KURSINSZKI, G.C. KITE, P.J. HOUGHTON, AND A. KERY. 2004. LC-MS analysis of antioxidant plant phenoloids. Chromatographia;60(1):S93-S100.

SHARMA G. AND G. LAMICHHANE. 2017. A review of plant based medicine in treatment of Urolithiatic disorder. The Pharma Innovation; 6(10):08-12.

SHIRFULE A.L., V. RACHARLA S.S. QADRI, AND A.L. KHANDARE. 2013. Exploring antiurolithic effects of gokshuradi polyherbal ayurvedic formulation in ethylene glycol-induced urolithiatic rats. Evidence-Based Complementary and Alternative Medicine; 11.

SHUKLA A.B., D.R. MANDAVIA, M.J. BARVALIYA, S.N. BAXI, AND C.R. TRIPATHI. 2014. Evaluation of anti-urolithiatic effect of aqueous extract of Bryophyllum pinnatum (Lam.) leaves using ethylene glycol-induced renal calculi. Avicenna journal of phytomedicine; 4(3):151.

SOFOWORA A. 1993. Medicinal Plants and Traditional Medicine in Africa. 2nd Edn., Spectrum Books Ltd., Ibadan, Nigeria, ISBN-13: 9782462195; p289

TUCAKOV J. AND J. BEOGRAD J. 1973. Izdavačko preduzeće "Rad", 624 (in Serbian).

VOGL S., P. PICKER, J. MIHALY-BISON, N. FAKH-RUDIN, A.G. ATANASOV, E.H. HEISS, C. WAWROSCH, G. REZNICEK, V.M. DIRSCH, J. SAUKEL, AND B. KOPP. 2013. Ethnopharmacological in vitro studies on Austria's folk medicine-An unexplored lore in vitro anti-inflammatory activities of 71 Austrian traditional herbal drugs. J. of Ethnopharmacology; 149(3):750-771.

VYSOCHINA,G.I., T.A. KUKUSHKINA, AND E.S. VASFILOV. 2013. Biologically Active Substances in Filipendula ulmaria (L.) Maxim. growing in the middle urals. Chemistry for Sustainable Development; (21):369-374.

Wang R., E.M. Younis, V.P. Veeraraghavan, and C. Tian. 2020. Antiurolithiatic effect of Fucoxanthin on ethylene glycol-induced renal calculus in experimental rats. J. King Saud University Science; 32(3):1896-1901. https://doi.org/10.1016/j.jksus.2020.01.027

WASHINGTON D.C. 2011. Guide for the Humane Care and Use of Laboratory Animals, National Research Council, NIH Publication No. 86-23. 


\title{
النشاط المضاد لمجرى البول لمستخلصات أوراق إكليله المروج في ذكور الجرذان البيضاء
}

\author{
رباب الجراري *1 - منى العمودي 2

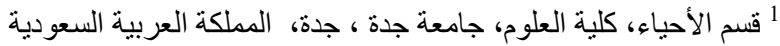

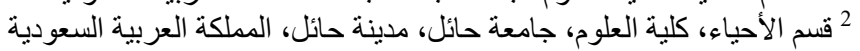 \\ الملخص العربــــي
}

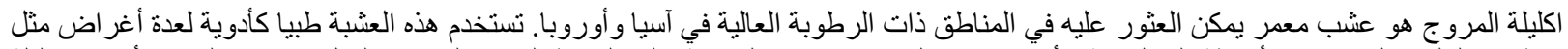

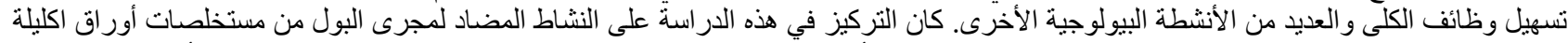

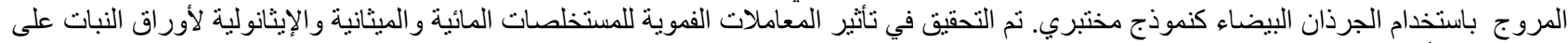

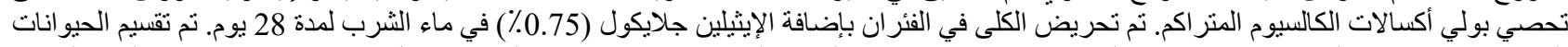

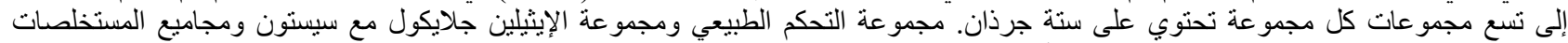

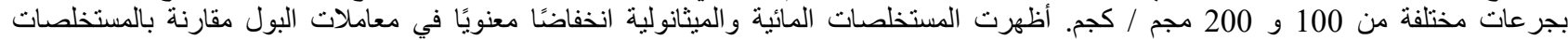

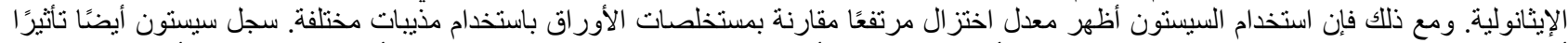

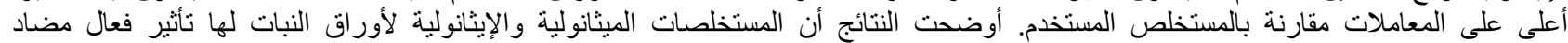
لليوروليثاتيك ضد التحصى البولي (إيثيلين جليكول) الناجم عن أكسالات الكالسيوم في ذكور الجرذان البنان البيضاء. 